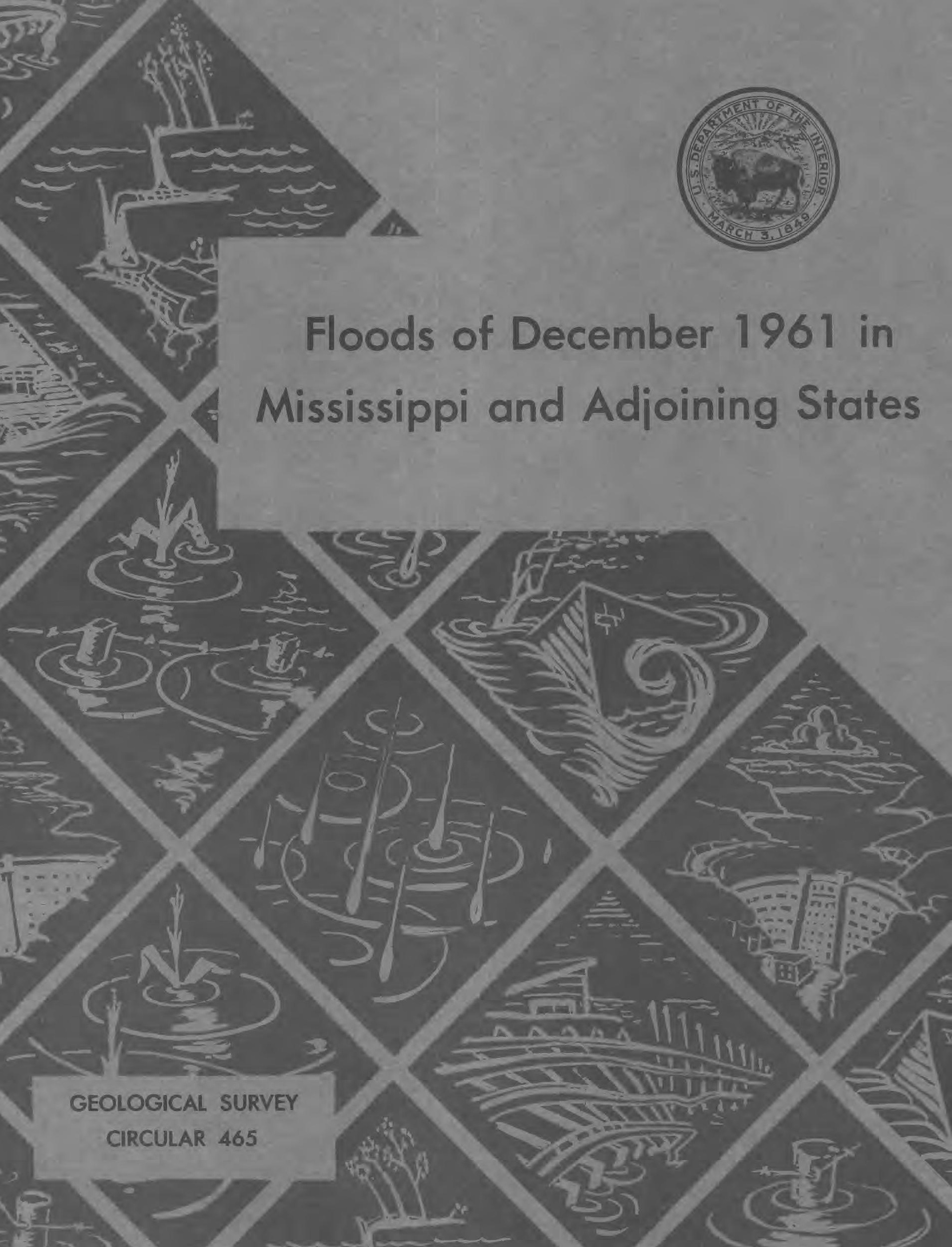




\section{Floods of December 1961 in \\ Mississippi and Adjoining States}

By James D. Shell

x

GEOLOGICAL SURVEY CIRCULAR 465 
United States Department of the Interior STEWART L. UDALL, SECRBTARY

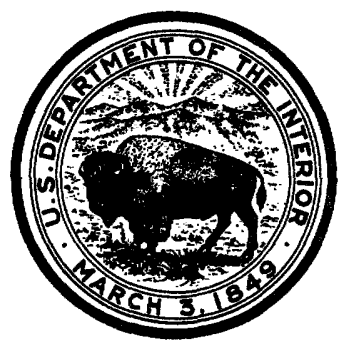

Geological Survey

THOMAS B. NOLAN, DIRBCTOR

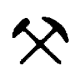

Free on application to the U.S. Geological Survey, Washington 25, D. C. 


\section{CONTENTS}

Page

Abstract

Page

Introduction...................... 1

General description of rainfall ...... 1

Description of flood............ 4

Flood damages

Aerial photography ............... 10

Streamflow data ................. 11

Records of discharge ......... 11

Summary of flood stages and discharges.................... 11

\section{ILLUSTRATIONS}

Figure 1. Isohyetal map of Mississippi and adjoining States, showing rainfall December 5-13,1961 _. . . .

2. Isohyetal map of Mississippi and adjoining States, showing rainfall December $14-18,1961 \ldots$

3. Isohyetal map of Mississippi and adjoining States, showing rainfall December 5-18, $1961 \ldots$

4. Aerial view showing flooded area along South State Street at Jackson, Miss ......

5. Aerial view showing flooded area along Gallatin Street in Jackson, Miss - .....-

6. Aerial view of Jackson, Miss., showing flooding near time of peak, December 21, 1961 .

7. Map of Mississippi and adjoining States, showing recurrence interval in years, of peak discharge at selected points, December 1961

8. Graph showing accumulated rainfall and stage of Sowashee Creek at Meridian, Miss., December 5-19, 1961 ........

9. Graph showing accumulated rainfall and stage of Pearl River at Edinburg, Miss., December 5-20, $1961 \ldots$

10. Map of Mississippi and adjoining States, showing location of flood profiles to be surveyed and aerial-photograph coverage, December 1961 .

Table 1. Rainfall, in inches, at selected sites in Louisiana, Mississippi, and Alabama for period December 5-18, 1961

2. Mean discharge (preliminary), in cubic feet per second, December 1961, of Pearl River at Edinburg, Miss -.

3. Mean discharge (preliminary), in cubic feet per second, December 1961, of Pearl River at Meeks Bridge near Canton, Miss _... . . .

4. Mean discharge (preliminary), in cubic feet per second, December 1961, of Pearl River at Jackson, Miss _...

5. Mean discharge (preliminary), in cubic feet per second, December 1961, of Big Black River near Bovina, Miss ........

6. Flood stages and discharges... 


\title{
Floods of December 1961 in Mississippi and Adjoining States
}

\author{
By James D. Shell
}

\begin{abstract}
Widespread floods occurred over parts of Mississippi, Louisiana, and Alabama after heavy rains during December 518,1961 . A series of low-pressure systems produced as much as 19 inches of rainfall in some areas. Heavy rainfall, 7 to 11 inches, on December 10 resulted in outstanding floods on small streams in southern Mississippi and southwestern Alabama. Subsequent rains produced multiple floods on small streams and outstanding floods of prolonged duration along the Big Black, upper Pearl, and lower Tombigbee Rivers in Mississippi.
\end{abstract}

At Jackson, Miss., the Pearl River reached the highest stage known. Along the east bank, flood waters topped or breached some of the levee system protecting the Flowood industrial area, but other parts were saved by extensive reinforcement and by emergency operation of the partially completed dam 10 miles upstream. Additional heavy damage to commercial and industrial property was prevented as a result of these measures.

Elsewhere, damage was restricted primarily to secondary highways and bridges. Two lives were lost.

\section{INTRODUCTION}

The data presented are intended to give a brief general account of the floods of December 1961 in Mississippi and in adjoining parts of Louisiana and Alabama that were affected significantly. Data for a complete report are not presently available but are being collected in anticipation of a more comprehensive report later.

These records were collected as a part of the cooperative programs between the U.S. Geological Survey and the various State agencies.

Work of the Surface Water Branch district personnel was directed by the following dis trict engineers: F. N. Hansen, Louisiana; W. H. Robinson, Mississippi, and L. E. Carroon, Alabama.
J.D. Shell, with advice and assistance of $H$. H. Barnes, Jr., flood specialist, collected and assembled the data. The report was prepared under the general supervision of Tate Dalrymple, chief, Floods Section, Washington, D. C. Various Federal, State, municipal, and private agencies furnished information and appropriate acknowledgment is given in the text.

\section{GENERAL DESCRIPTION OF RAINFALL}

A series of weather fronts associated with low-pressure systems, migrating northeastward from northern Mexico and the lower Rio Grande Valley, moved over Louisiana, Mississippi, and Alabama during the period December 5-18, 1961. These systems collided with cold-air masses moving southeastward from the Rocky Mountain area and resulted in a prolonged storm period during which rain fell in amounts totaling as much as 19 inches.

During the period December 5-9, rainfall was light over much of the area, with an average accumulation of approximately $1 \frac{1}{2}$ inches. This precipitation produced no appreciable rises on the streams but did soak the ground thoroughly and caused high percentages of runoff from precipitation that fell later.

On December 10, heavy rain fell on a narrow belt extending from Bogalusa, La, northeastward through southern Mississippi and into southwestern Alabama along a line from Washington County to Wilcox County. Along this narrow band, as much as 11 inches of precipitation was measured. At Bogalusa, La., 9.78 inches was measured. Immediately to the east of Bogalusa, in the White Sand community of Pearl River County, Miss., 10.52 
inches fell early on December 10. Other areas of heavy precipitation were in southeastern Mississippi at Beaumont, with 11.42 inches, and in Alabama at Pinehill, Millers Ferry, and Selma, each receiving more than 7 inches of rainfall.

Precipitation continued on December 11 and 12 , with the heavier precipitation in central Mississippi over the Pearl and Big Black River basins. The isohyetal map (fig. 1) based on rainfall data furnished by the U.S. Weather Bureau and the Mississippi Forestry Com- mission shows storm rainfall for the period December 5-13. During the second storm period, December 14-18, heavier rains again fell over the Pearl and Big Black River basins, as indicated by the isohyetal map of rainfall for that period (fig. 2). The isohyetal map for the entire period, December $5-18$, is shown on figure 3 . These isohyetal maps are necessarily generalized because of the variations of intensity and accumulation. Figures of daily rainfall for a few selected stations in the area, shown in table 1, give detailed daily distribution of the precipitation.

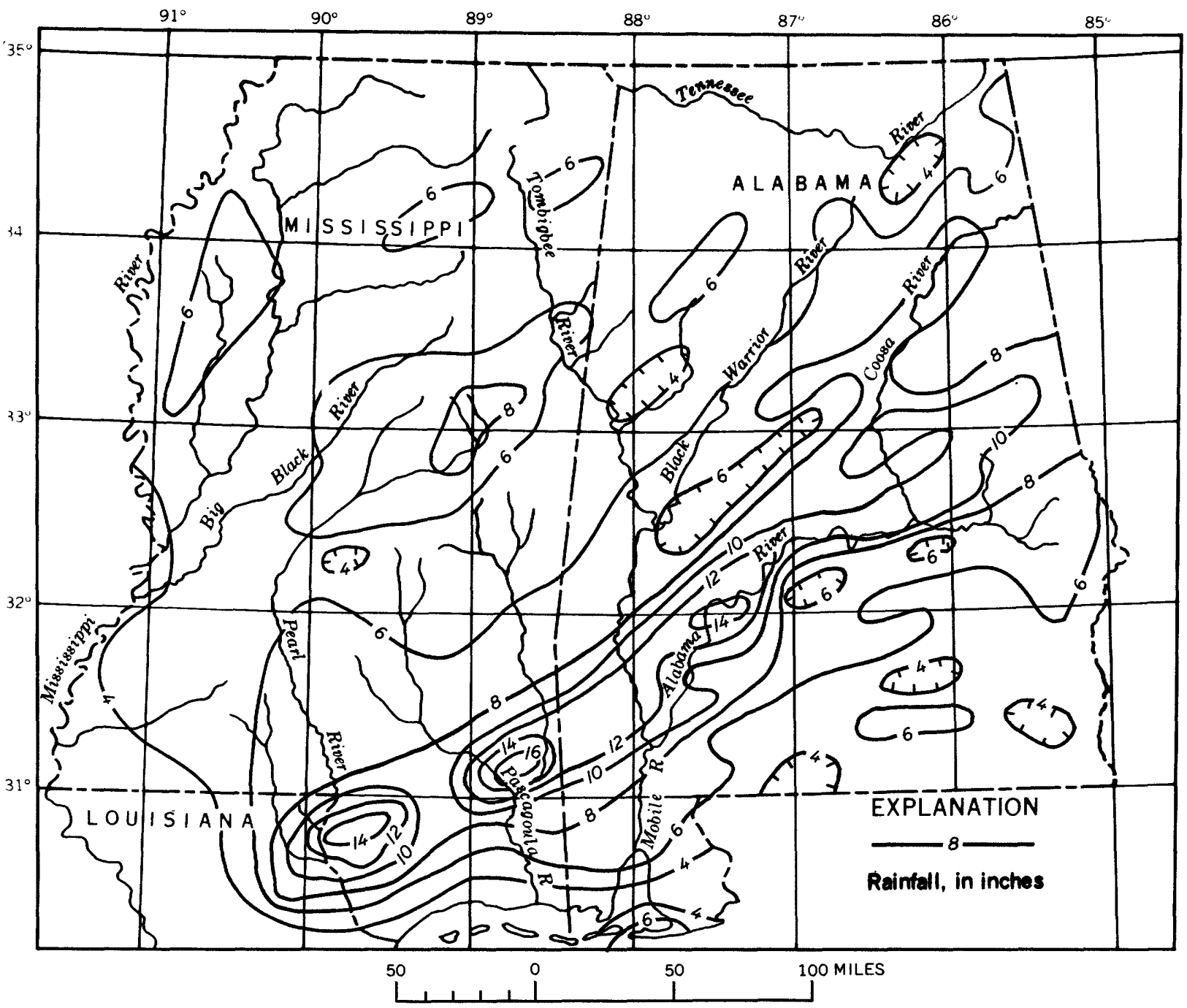

Figure 1. - Isohyetal map of Mississippi and adjoining States, showing rainfall December 5-13, 1961. 


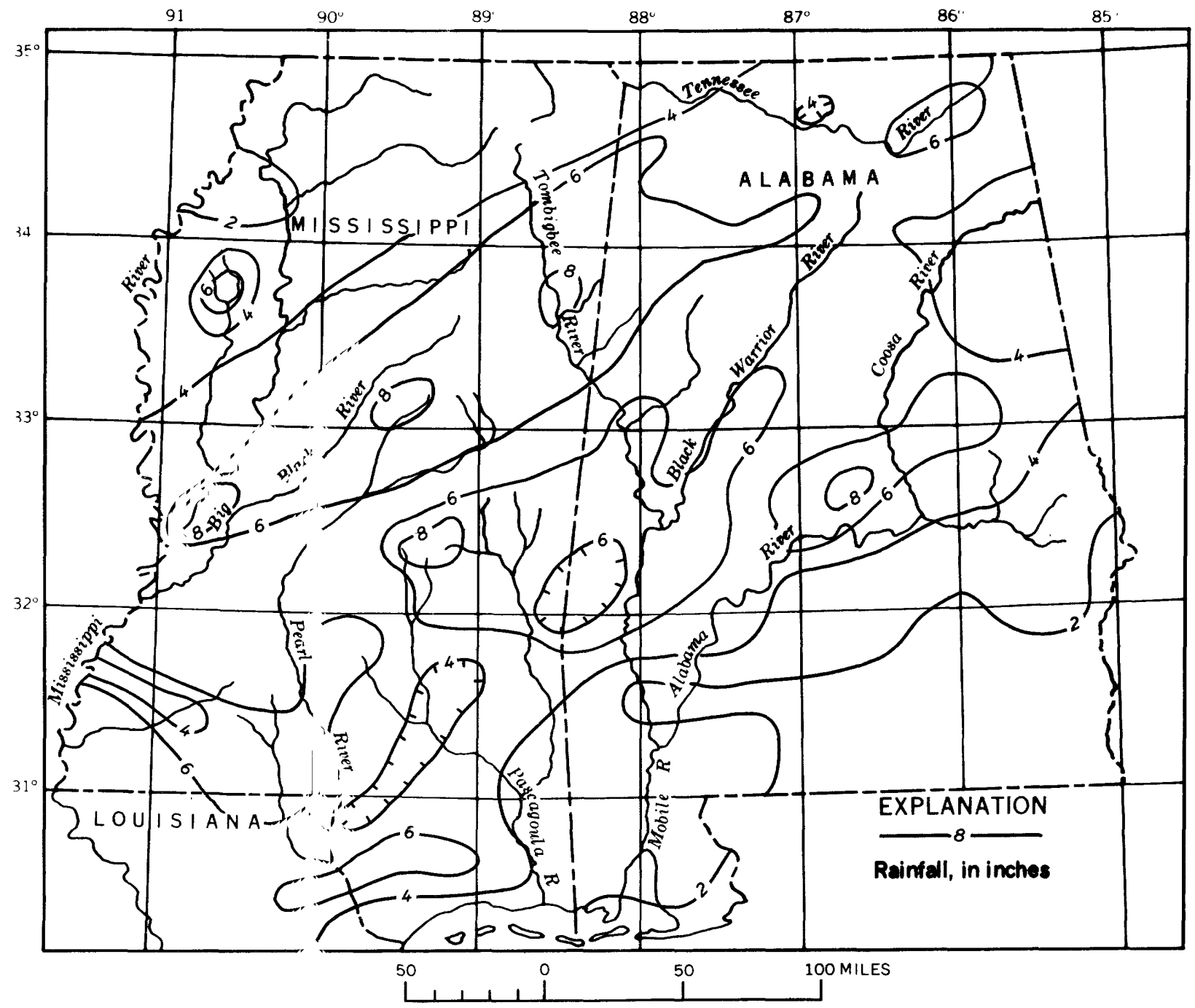

Figure 2. - Isohyetal map of Mississippi and adjoining States, showing rainfall December 14-18, 1961.

'Table 1. -Rainfall, in inches, at selected sites in Louisiana, Mississippi, and Alabama for period December 5-18, 1961

\begin{tabular}{|c|c|c|c|c|c|c|c|c|c|c|c|c|c|c|c|}
\hline \multirow{2}{*}{ Station } & \multicolumn{14}{|c|}{ December } & \multirow{2}{*}{ Total } \\
\hline & 5 & 6 & 7 & 8 & 9 & 10 & 11 & 12 & 13 & 14 & 15 & 16 & 17 & 18 & \\
\hline 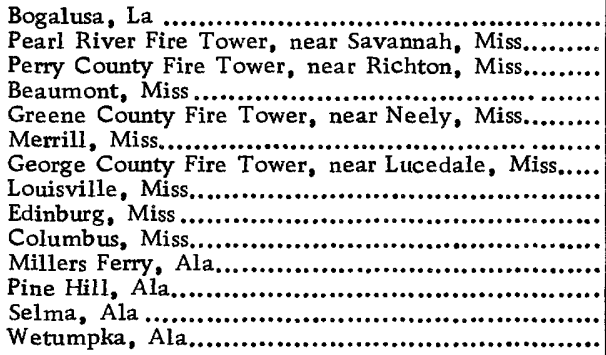 & $\begin{array}{l}0 \\
0 \\
0 \\
0 \\
0 \\
.05 \\
0 \\
.78 \\
.78 \\
.31 \\
0 \\
0 \\
0 \\
0 \\
0\end{array}$ & $\mid \begin{array}{c}0.14 \\
0 \\
.33 \\
.06 \\
.30 \\
.18 \\
.25 \\
.71 \\
1.41 \\
.68 \\
0 . \\
0 \\
0 \\
0\end{array}$ & $\mid$\begin{tabular}{l|}
0 \\
0 \\
.08 \\
.06 \\
.08 \\
.01 \\
.10 \\
.01 \\
.25 \\
.14 \\
0 \\
0 \\
0 \\
0
\end{tabular} & $\begin{array}{l}0 \\
.28 \\
0 \\
0 \\
0 \\
0 \\
0 \\
0 \\
0 \\
0 \\
0 \\
0 \\
0 \\
0\end{array}$ & $\begin{array}{r}0.08 \\
1.08 \\
.25 \\
.08 \\
.64 \\
0 \\
1.00 \\
.27 \\
.40 \\
.15 \\
.21 \\
0 \\
.13 \\
.14\end{array}$ & $\begin{array}{r}9.78 \\
7.87 \\
4.75 \\
11.42 \\
9.64 \\
6.18 \\
5.00 \\
1.65 \\
1.53 \\
.84 \\
7.75 \\
7.80 \\
7.08 \\
8.10\end{array}$ & $\begin{array}{r}0.96 \\
.88 \\
.27 \\
.58 \\
2.00 \\
1.30 \\
2.00 \\
.15 \\
.03 \\
1.09 \\
.31 \\
.85 \\
.10 \\
1.60\end{array}$ & $\begin{array}{l}1.76 \\
2.63 \\
1.22 \\
.67 \\
3.27 \\
.43 \\
1.25 \\
5.16 \\
3.51 \\
2.77 \\
1.45 \\
2.95 \\
1.67 \\
2.60\end{array}$ & \begin{tabular}{|r|}
$1: 08$ \\
.46 \\
.45 \\
2.25 \\
.52 \\
1.94 \\
1.00 \\
.03 \\
.19 \\
.03 \\
2.56 \\
2.58 \\
1.90 \\
2.00
\end{tabular} & $\mid \begin{array}{c}0.19 \\
.08 \\
.55 \\
.43 \\
.40 \\
.04 \\
.10 \\
.48 \\
.60 \\
0 . . \\
.39 \\
.92 \\
.28 \\
.32\end{array}$ & $\begin{array}{r}0.86 \\
1.14 \\
.85 \\
.37 \\
.78 \\
.48 \\
1.00 \\
1.02 \\
2.15 \\
.66 \\
1.26 \\
.72 \\
1.50 \\
2.27\end{array}$ & \begin{tabular}{|}
0.17 \\
.57 \\
.34 \\
.49 \\
.15 \\
1.30 \\
.75 \\
.67 \\
.18 \\
.14 \\
.54 \\
0 \\
.66 \\
.52
\end{tabular} & \begin{tabular}{|}
1.82 \\
2.50 \\
.82 \\
1.83 \\
.85 \\
.13 \\
.25 \\
1.34 \\
1.58 \\
3.19 \\
.10 \\
0.38 \\
.38 \\
.31
\end{tabular} & $\begin{array}{r}1.21 \\
1.76 \\
2.41 \\
1.32 \\
1.05 \\
.65 \\
.60 \\
2.45 \\
2.07 \\
2.61 \\
1.84 \\
2.77 \\
3.85 \\
1.07\end{array}$ & $\begin{array}{l}18.09 \\
19.25 \\
12.38 \\
19.56 \\
19.68 \\
12.69 \\
13.30 \\
14.72 \\
14.23 \\
12.64 \\
16.41 \\
18.59 \\
17.55 \\
18.93\end{array}$ \\
\hline
\end{tabular}




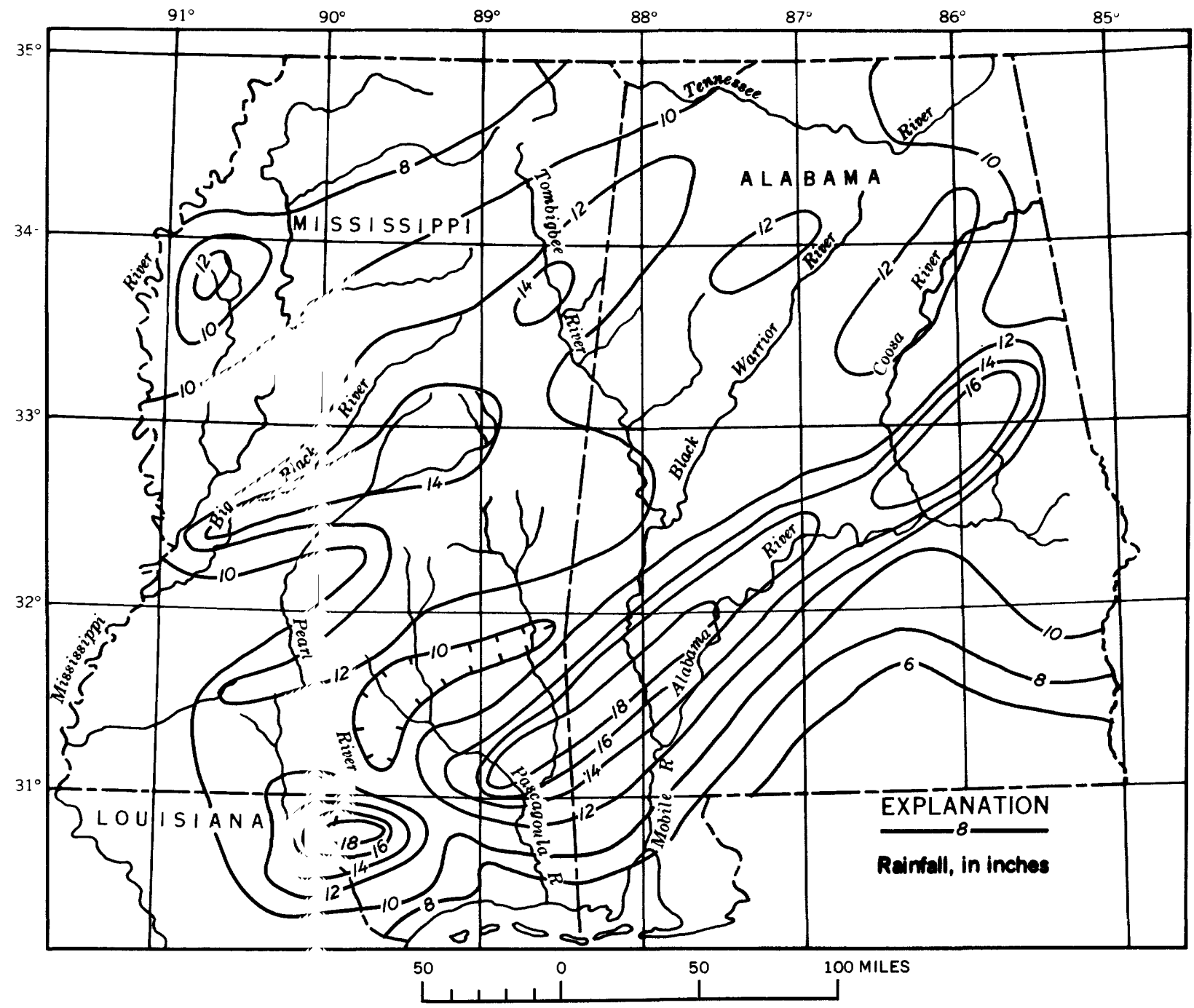

Figure 3. - Isohyetal map of Mississippi and adjoining States, showing rainfall December 5-18, 1961.

\section{DESCRIPTION. OF FLOOD}

In general, only on small streams or on streams with short records of streamflow did the flood peaks exceed previous maximums. A few small streams, notably in the Pearl and Pascagoula River basins, reached peaks with recurrence intervals of 50 years or more.

Peak discharges along the main stem of the Pearl River ranged from a 12 -year flood at Edinburg to a 25-year flood at Jackson, then flattened to an 8-year flood at Columbia. At Jackson, Miss., the Pearl River reached the highest stage known; the peak stage was slightly higher than the previous maximum. in 1902 , although the peak discharge was less than that of 1902 .
The east side of the flood plain at Jackson is occupied by an extensive network of ring levees north of U.S. Highway 80 that protect commercial and industrial property. This area is commonly known as Flowood. Some of the levees were overtopped, and only through coordinated efforts of municipal, county, and State agencies were some levees raised high enough to prevent the entire area from being flooded. Two gates of the spillway section of the partially completed dam on the Pearl River approximately 10 miles upstream from Jackson were closed late on December 20 to reduce the anticipated flood crest in the Flowood area. It was estimated that the crest at the gaging station at Jackson was reduced approximately 0.2 foot as a result of this action. 


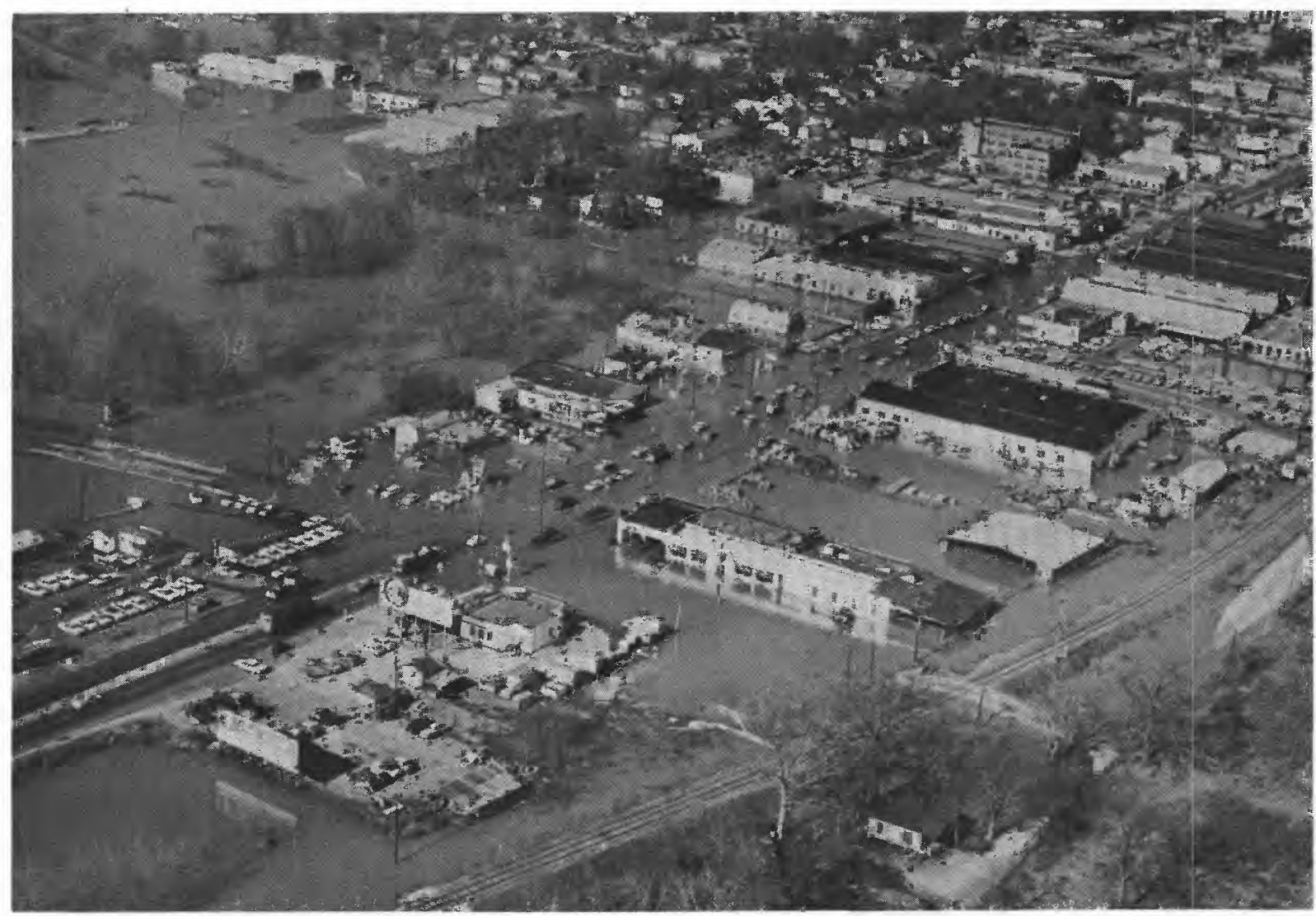

Figure 4. -Aerial view showing flooded area along South State Street, Jackson, Miss.

U.S. Highway 80 , linking Jackson and Flowood, was overtopped, but traffic was maintained by sandbagging critical points along the westbound lane. U.S. Highway 51, railroads, some principal streets, and commercial and residential property in southeast Jackson were flooded (fig. 4 and 5).

The extent of flooding by the Pearl River in the Jackson-Flowood area is shown in the aerial photograph taken by the Mississippi Air National Guard near the crest on December 21, 1961 (fig. 6).

The extended duration of flooding on the Pearl River is noteworthy. At Jackson the Pearl River reached flood stage (18 feet) on December 11, 1961, and remained above this point until February 13, 1962, a period of 65 days, as a result of the reported storm and subsequent rainfall. Prolonged high stages during the period- -32 days above a stage of 28 feet-delayed repairs to the damaged levee system. It is of interest to note that from February 19, 1961, to F ebruary 13, 1962 , Pearl River at Jackson was above flood stage a total of 127 days.

Downstream, at Bogalusa, La., the Pearl River reached an initial peak discharge of 55,600 cfs on December 20 as a result of heavy rainfall during the period December 513. The river then fell slightly but rose again as the upstream crest approached. It reached a peak discharge of $70,800 \mathrm{cfs}$ on December 29 , which has a recurrence interval of about 14 years.

Immediately east of Bogalusa, La., in Pearl River County, Miss., floods on small streams were outstanding. East Hobolochitto Creek at Highway 26, at White Sand, reached a stage 


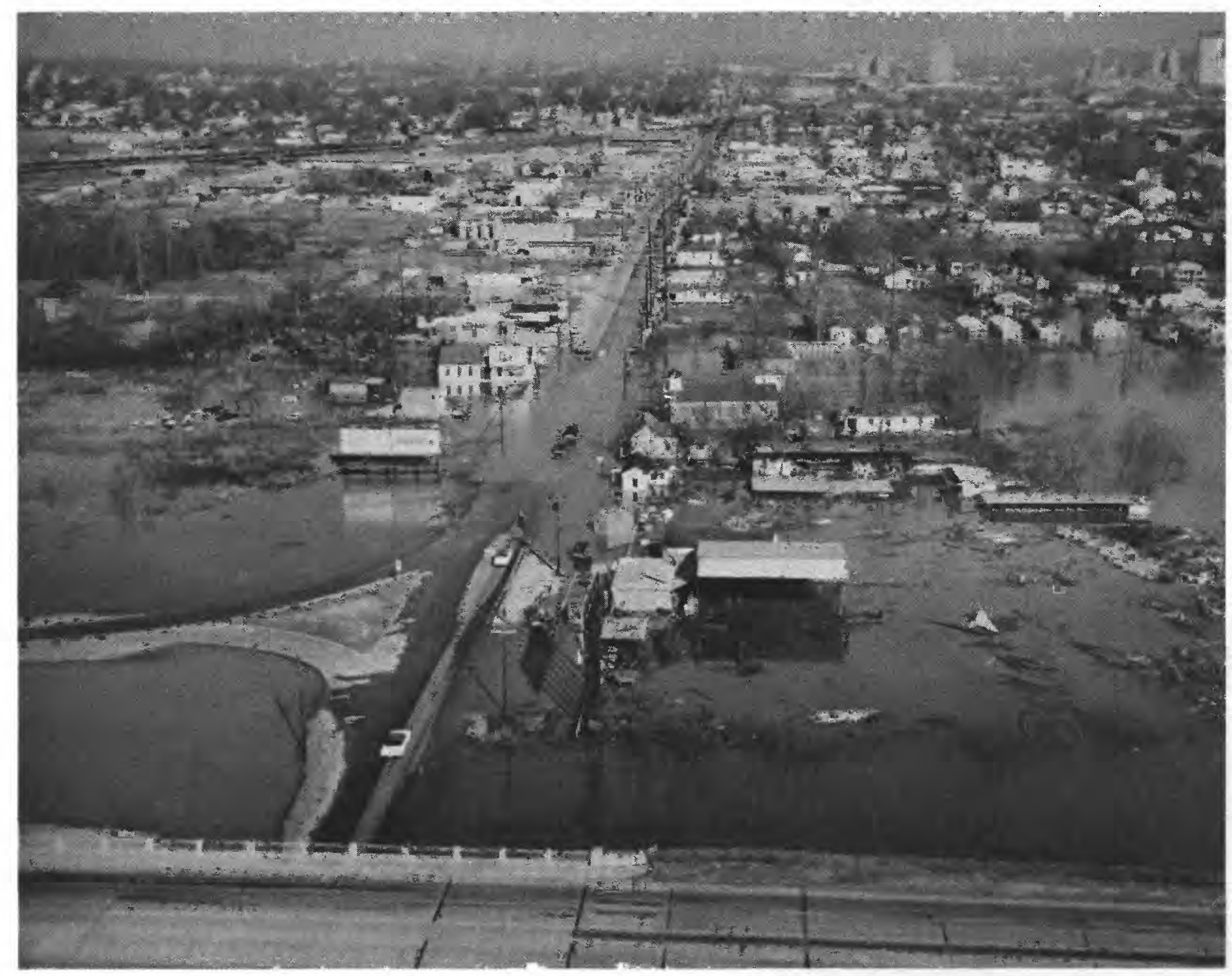

Figure 5.-Aerial view showing flooded area along Gallatin Street, Jackson, Miss.

0.3 foot higher than the peak stage in February 1961 , and reached a peak discharge known to be in excess of a 50-year flood. The creek overflowed its banks and flooded many houses in the White Sand community.

Peak discharges on the upper Tombigbee River reflected the long duration and fairly even distribution of rainfall in northeastern Mississippi during the entire storm period. At Columbus the runoff from the several rainstorms coincided to produce a peak discharge of about a 21 -year recurrence interval. Upstream from Columbus, the peaks were of progressively lower recurrence interval-12 years at Aberdeen and 8 years near Amory-whereas on the tributaries upstream from Amory the peak discharges had recurrence intervals ranging generally from 1 to 3 years. A map (fig. 7) showing recur- rence intervals of peak discharge at selected points indicates flood peaks of smaller frequencies at sites on the tributary streams than at sites on the larger streams, where drainage areas are larger and precipitation time is longer.

At Columbus, U.S. Highway 82 was overtopped and closed, as was Mississippi Highway 50. Floodwater inundated much of the area west of the rivers in the Columbus area. Many industries were forced to suspend operations and an estimated 45 families were evacuated.

The multicrest response of small streams to the time distribution of storm rainfall compared with the single crest of long duration on large streams is illustrated by figures 8 and 9. 


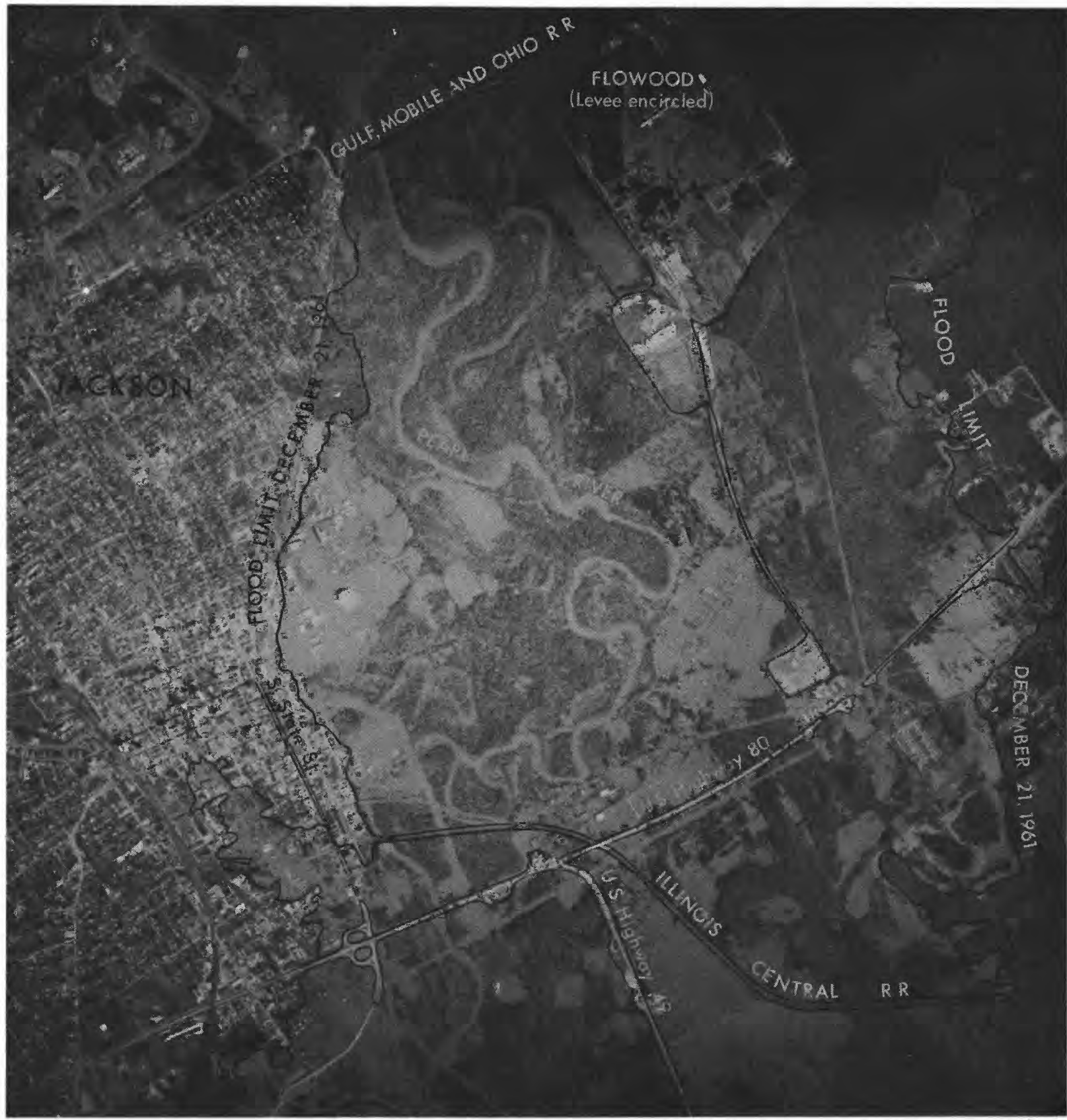

Figure 6. - Aerial view of Jackson, Miss., showing flooding by Pearl River near time of peak, December 21, 1961. Photograph by Mississippi Air National Guard. 


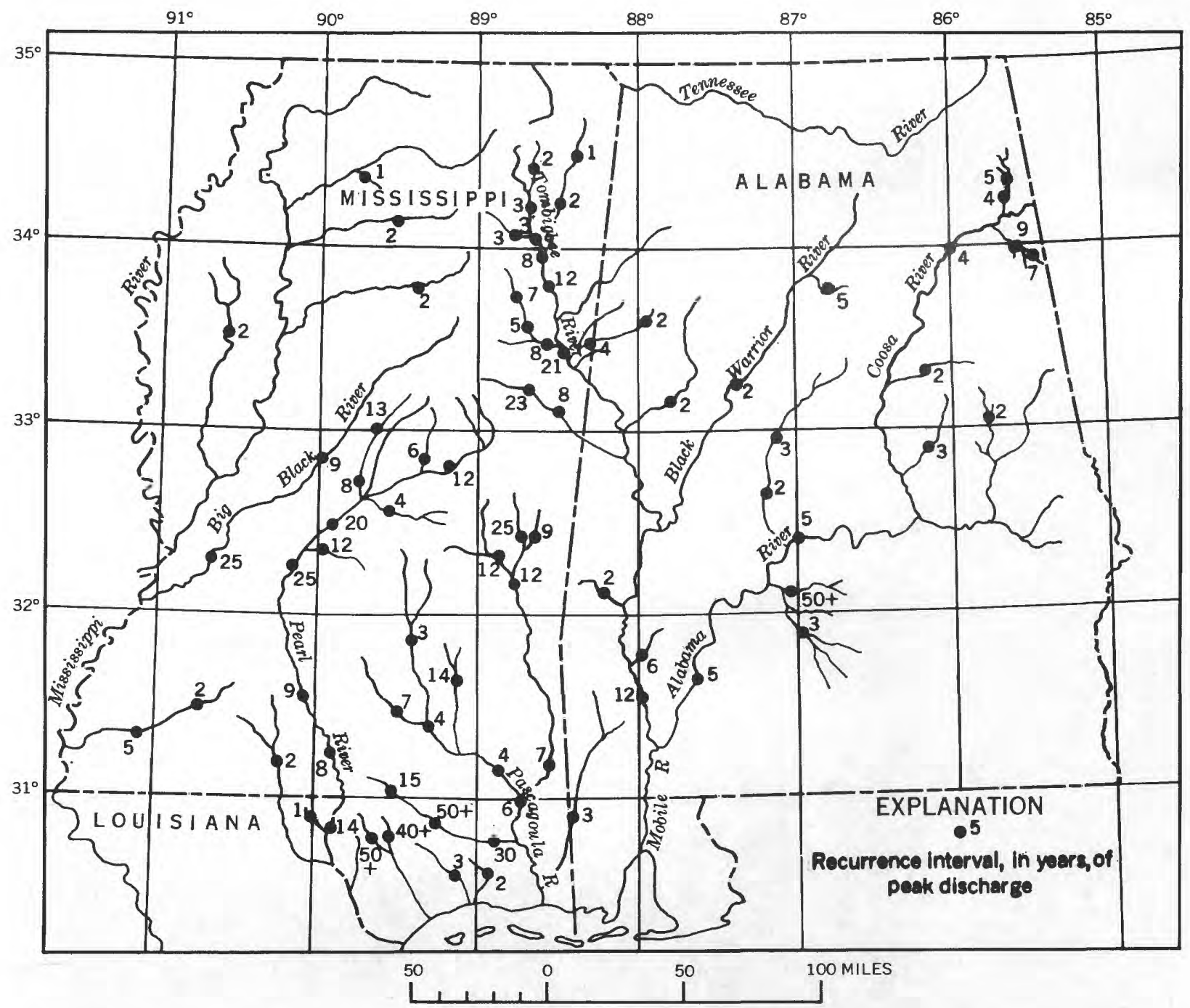

Figure 7. - Map of Mississippi and adjoining States, showing recurrence intervals of peak discharge at selected points, December 1961. 

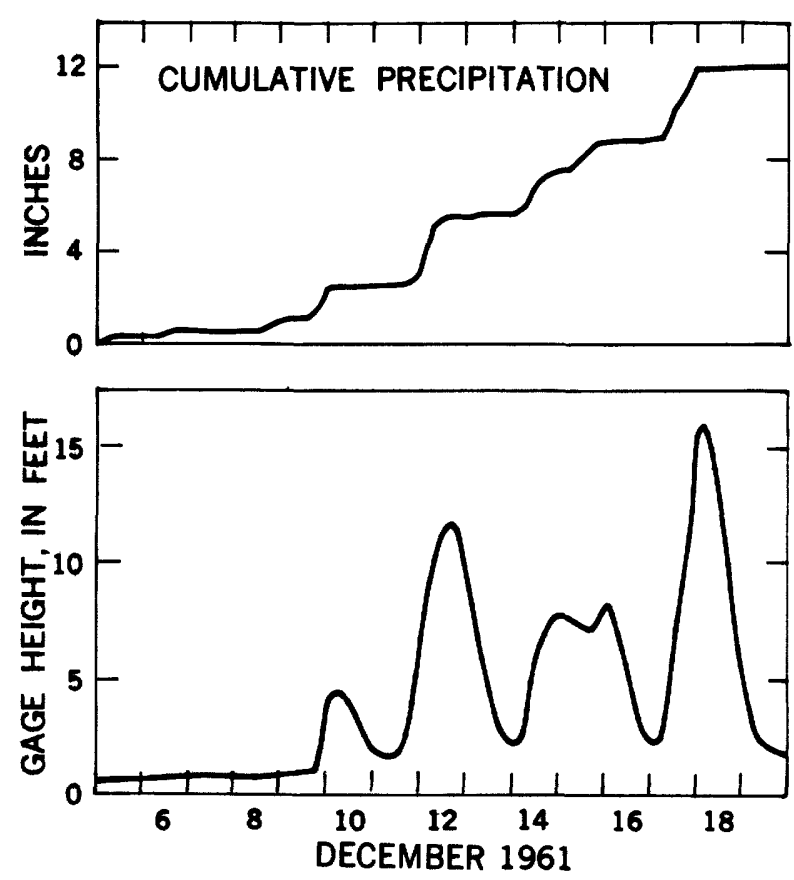

Figure 8. -Graph showing accumulated rainfall and stage of Sowashee Creek at Meridian, Miss. (drainage area, 51.9 sq mi), December 5-19, 1961.
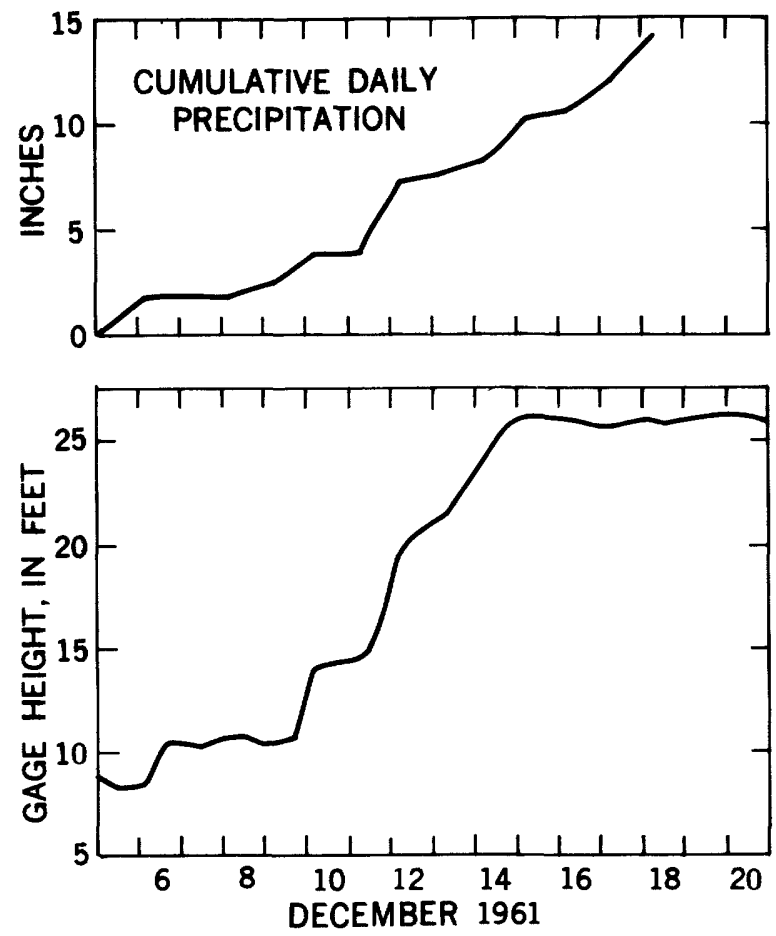

Figure 9.-Graph showing accumulated rainfall and.stage of Pearl River at Edinburg, Miss. (drainage area, $898 \mathrm{sq} \mathrm{mi}$ ), December $5-20,1961$.

\section{FLOCD DAMAGES}

Damage resulting from the flood was limited mostly to highways and to municipal and industrial property in the Jackson, Miss., area. Because the flood occurred in the winter, agricultural damage was light and no estimates of it was made. Two persons were drowned in Mississippi.

Pearl River County, Miss., sustained very heavy damage to roads and bridges, especially on the secondary road system. About 1,000 feet of newly constructed road was washed out. Estimates by the county engineer placed the damage to roads and bridges at about a quarter of a million dollars.

A preliminary estimate made by the Mississippi Highway Department placed the total damage to all secondary roads in the State at $\$ 1$ million. Estimates of damage to major highways in the State by districts were as follows:

\begin{tabular}{|c|c|c|}
\hline District & Area in State & \\
\hline 1 & Northeast _. & $\$ 25,00$ \\
\hline 2 & Northwest & 6,000 \\
\hline 3 & West central & 30,000 \\
\hline 5 & East central _... & 20,000 \\
\hline 6 & Southeast & 35,000 \\
\hline 7 & Southwest_._._... & 36,300 \\
\hline
\end{tabular}

Total _...

The Alabama Highway Department made no complete cost estimate but reported damage to highways in at least 10 counties, principally in southwestern Alabama. In Marengo County there was appreciable damage to 6 bridges or fills, and 9 sections of highway were inundated. In Clarke County 2 bridges were damaged. In Fayette County the Sipsey River overtopped a county road near Hubbertville, causing damage estimated at $\$ 15,500$. In Wilcox County there was extensive damage to State and county roads along Goose and Turkey Creeks in the vicinity of Kimbrough. Other counties in the area reported lesser damage.

Industrial damage and cost of flood protection in the Flowood area east of Jackson, Miss., was estimated as follows by Mayor Flynn of Flowood: 
Knox Glass Co

Other industries (total) ...... 30,000

Cost of maintaining Flowood

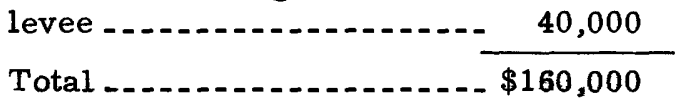

Complete data on damages to private property are not available. According to incomplete figures furnished by the American $\mathrm{Na}$ tional Red Cross, 567 residences were flooded in the Jackson, Miss., area and about 45 at Columbus, Miss.

\section{AERIAL PHOTOGRAPHY}

Aerial photographs by the Mississippi Air National Guard covered flooded areas along the main stems of the Pearl, Big Black, and Tombigbee Rivers, as indicated on the map, figure 10. These photographs, taken during

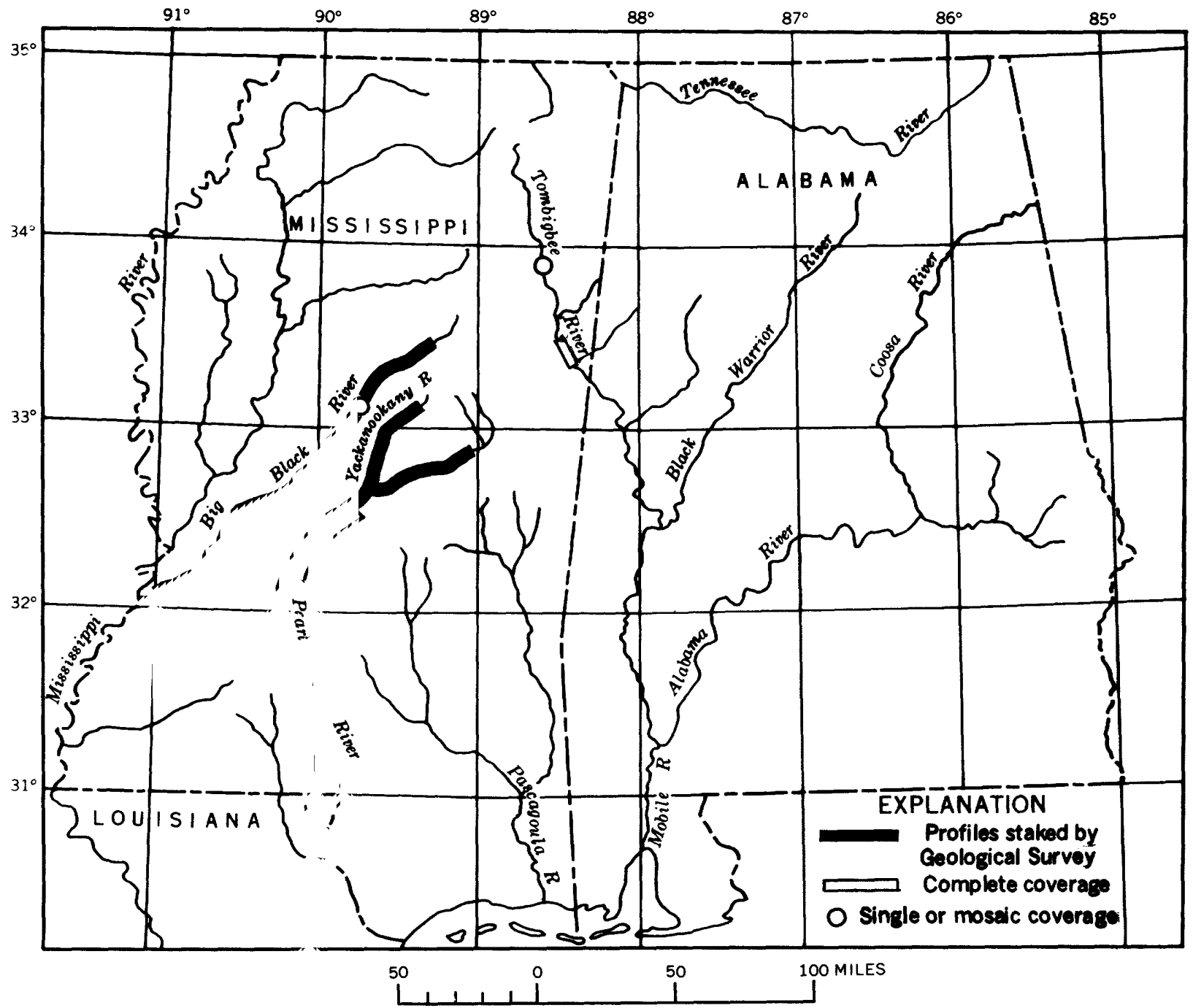

Figure 10. - Map of Mississippi and adjoining States, showing aerial-photograph coverage and location of flood profiles to be surveyed, December 1961. 
or near the crest stage, are available for use in inundation mapping.

\section{RIVER PROFILES}

At selected points along the Big Black, Pearl, and Yockanookany Rivers in central Mississippi, high-water marks were staked to define the flood profiles. From survey of these marks about 360 stream miles of flood profiles are being developed as is shown in figure 10.

In the Jackson area along Pearl River, the flood profiles were defined in more detail in anticipation of an inundation map now in preparation.

\section{STREAMFLOW DATA}

RECORDS OF DISCHARGE

At 3 stations on Pearl River and 1 on Big Black River preliminary figures of daily and monthly discharge and runoff, in inches, for December 1961 are given in tables 2-5. At all 4 stations, Pearl River at Edinburg, at Meeks Bridge near Canton, and at Jackson and Big Black River at Bovina, the floods were not eworthy.

\section{SUMMARY OF FLOOD STAGES AND DISCHARGES}

Flood stages and discharges are summarized in table 6 . The table gives in downstream order the station name, drainage area, and the maximum stage and discharge of record prior to and during December 1961 with date of occurrence; and recurrence interval, $T$, of the December 1961 peaks. Re currence intervals with a plus sign $(t)$ indicate that the recurrence interval can be much greater than the interval shown. 
Table 2.-Mean discharge (preliminary), in cubic feet per second, December 1961, of Pearl River at Edinburg, Miss.

\begin{tabular}{r|r||r|r||r|r||r|r}
\hline \multicolumn{1}{c|}{ Day } & \multicolumn{1}{|c|}{ Discharge } & \multicolumn{1}{c|}{ Day } & Discharge & Day & Discharge & Day & Discharge \\
\hline Dec. 1 & 1,920 & Dec. 9 & 1,840 & Dec. 17 & 21,000 & Dec. 25 & 5,280 \\
2 & 1,790 & 18 & 21,300 & 26 & 4,470 \\
3 & 1,620 & 11 & 3,750 & 19 & 23,400 & 27 & 3,620 \\
4 & 1,410 & 12 & 5,650 & 20 & 24,400 & 28 & 2,860 \\
5 & 1,210 & 13 & 7,670 & 21 & 18,600 & 29 & 2,350 \\
6 & 1,500 & 14 & 16,100 & 22 & 12,400 & 30 & 2,020 \\
7 & 1,720 & 15 & 23,400 & 23 & 8,810 & 31 & 1,880 \\
8 & 1,770 & 16 & 21,800 & 24 & 6,520 & & \\
\hline
\end{tabular}

Table 3.-Mean discharge (preliminary), in cubic feet per second, December 1961, of Pearl River at Meeks Bridge, near Canton, Miss.

\begin{tabular}{r|r||r|r||r|r||r|r}
\hline \multicolumn{1}{c|}{ Day } & \multicolumn{1}{c|}{ Discharge } & \multicolumn{1}{c|}{ Day } & Discharge & Day & Discharge & Day & Discharge \\
\hline Dec. 1 & 3,460 & Dec. 9 & 3,840 & Dec. 17 & 42,300 & Dec. 25 & 31,000 \\
2 & 2,800 & 10 & 4,720 & 18 & 55,500 & 26 & 24,500 \\
3 & 2,180 & 11 & 6,020 & 19 & 62,500 & 27 & 20,000 \\
4 & 1,890 & 12 & 8,790 & 20 & 65,400 & 28 & 16,100 \\
5 & 1,770 & 13 & 12,200 & 21 & 64,800 & 29 & 12,800 \\
6 & 1,900 & 14 & 17,200 & 22 & 59,500 & 30 & 10,100 \\
7 & 2,280 & 15 & 22,300 & 23 & 49,400 & 31 & 7,880 \\
8 & 2,950 & 16 & 28,900 & 24 & 39,000 & & \\
\hline
\end{tabular}

Table 4.-Mean discharge (preliminary), in cubic feet per second, December 1961 of Pearl River at Jackson, Miss.

\begin{tabular}{|c|c|c|c|c|c|c|c|}
\hline Day & Discharge & Day & Discharge & Day & Discharge & Day & Discharge \\
\hline litc. 1 & 4,970 & Dec. 9 & 4,450 & Dec. 17 & 34,900 & Dec. 25 & 51,200 \\
\hline 2 & 4,360 & 10 & 6,130 & 18 & 43,500 & 26 & 43,300 \\
\hline 3 & 3,670 & 11 & 6,750 & 19 & 53,500 & 27 & 35,200 \\
\hline 4 & 2,960 & 12 & 10,700 & 20 & 62,800 & 28 & 27,900 \\
\hline 5 & 2,620 & 13 & 12,000 & 21 & 64,900 & 29 & 21,600 \\
\hline 6 & 2,490 & 14 & 16,000 & 22 & 64,500 & 30 & 17,200 \\
\hline 7 & 2,600 & 15 & 21,400 & 23 & 63,000 & 31 & 14,600 \\
\hline 8 & 3,280 & 16 & 25,400 & 24 & 58,200 & & \\
\hline
\end{tabular}

Monthly mean, in cubic feet per second . . . . . . . .

Runoff, in inches . . . . . . . .

Table 5.-Mean discharge (preliminary), in cubic feet per second, December 1961, of Big Black River near Bovina, Miss.

\begin{tabular}{r|r||r|r||r|r||r|r}
\hline \multicolumn{1}{c|}{ Day } & \multicolumn{1}{|c|}{ Discharge } & \multicolumn{1}{c|}{ Day } & Discharge & Day & Discharge & Day & Discharge \\
\hline Dec. 1 & 7,580 & Dec. 9 & 6,940 & Dec. 17 & 46,200 & Dec. 25 & 39,400 \\
2 & 7,620 & 10 & 8,590 & 18 & 53,900 & 26 & 32,100 \\
3 & 7,480 & 11 & 9,400 & 19 & 59,100 & 27 & 26,800 \\
4 & 7,140 & 12 & 11,700 & 20 & 63,100 & 28 & 23,000 \\
5 & 6,670 & 13 & 12,100 & 21 & 62,300 & 29 & 19,900 \\
6 & 6,650 & 14 & 14,800 & 22 & 57,600 & 30 & 17,200 \\
7 & 6,950 & 15 & 20,400 & 23 & 51,800 & 31 & 15,000 \\
8 & 6,800 & 16 & 28,800 & 24 & 46,000 & & \\
\hline
\end{tabular}


STREAMFLOW DATA

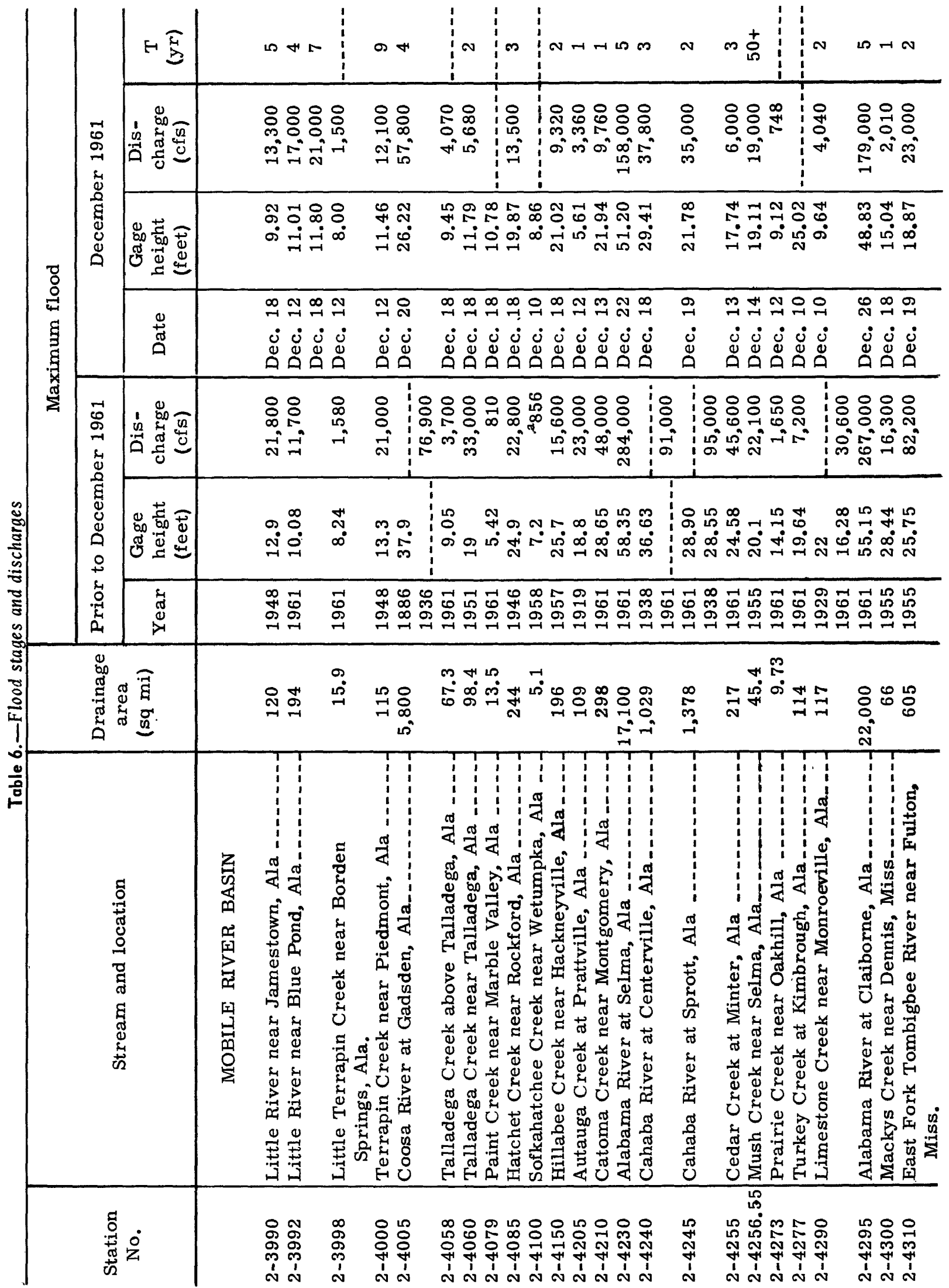




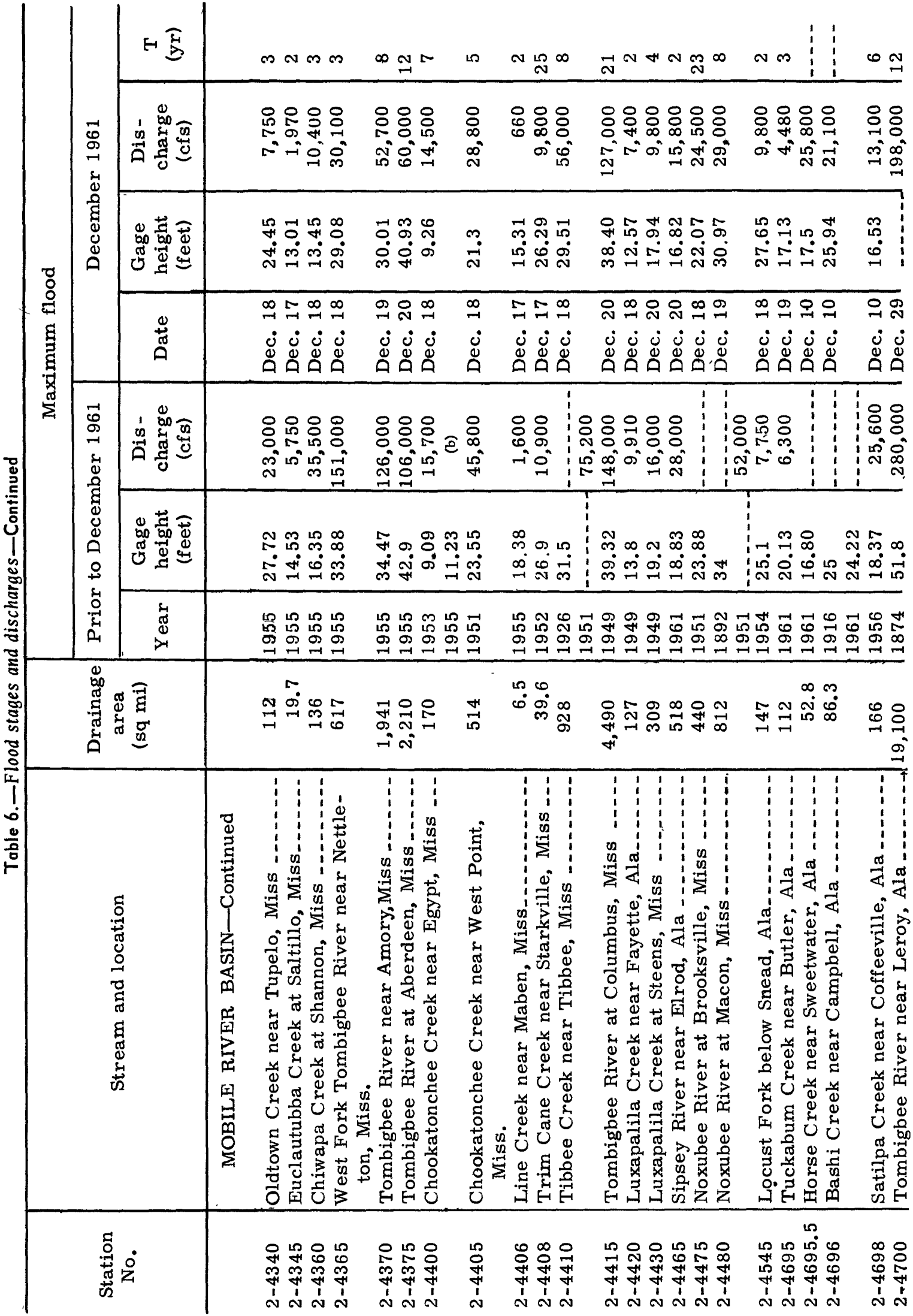




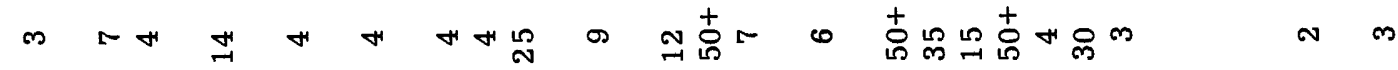

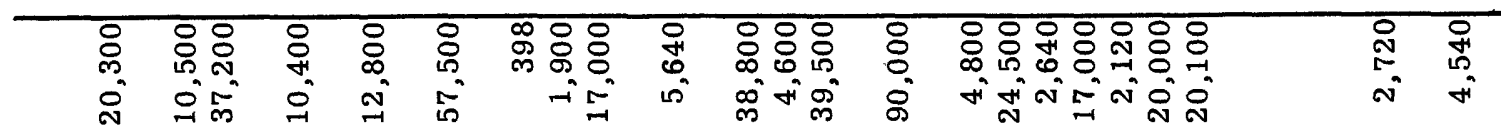

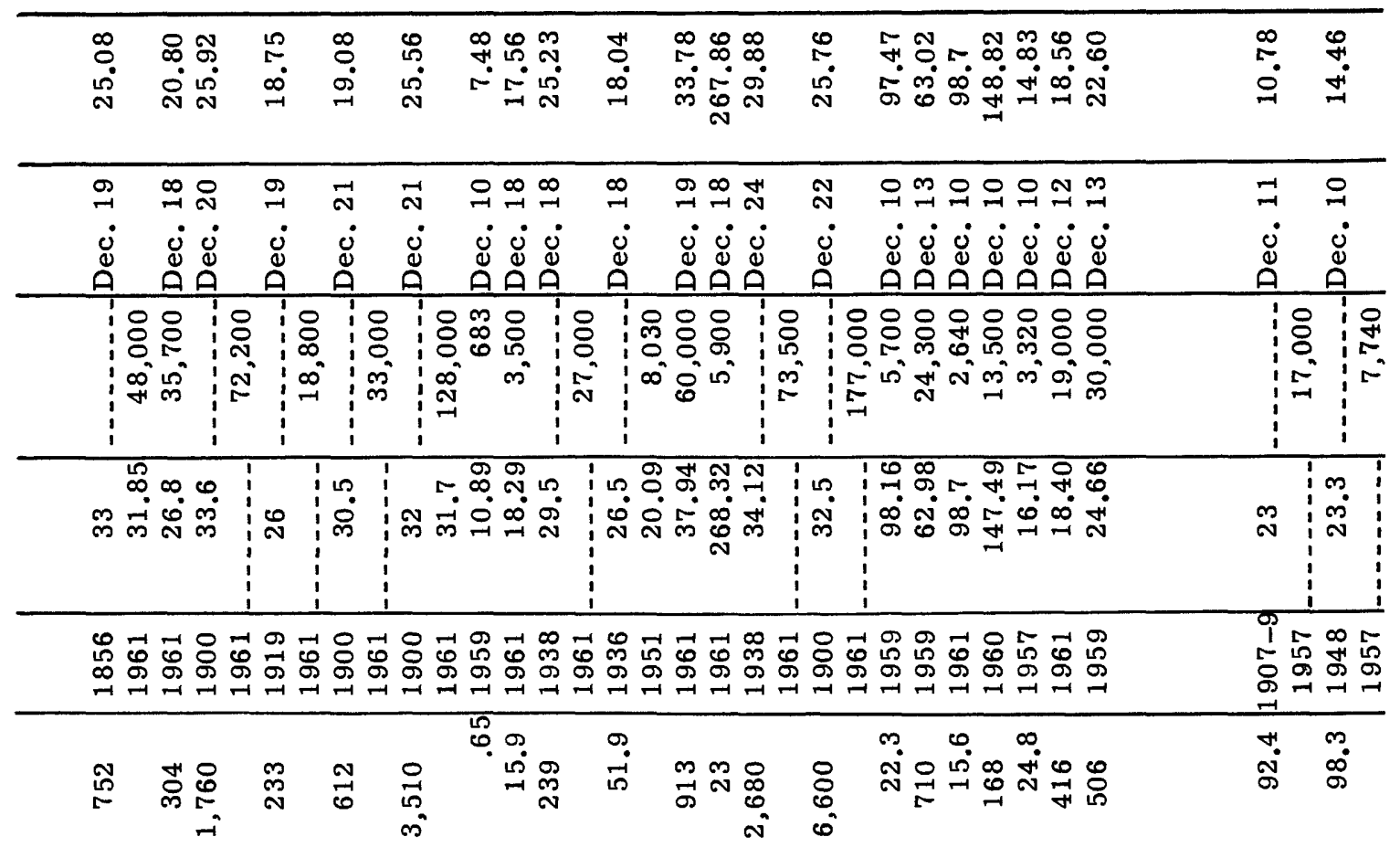

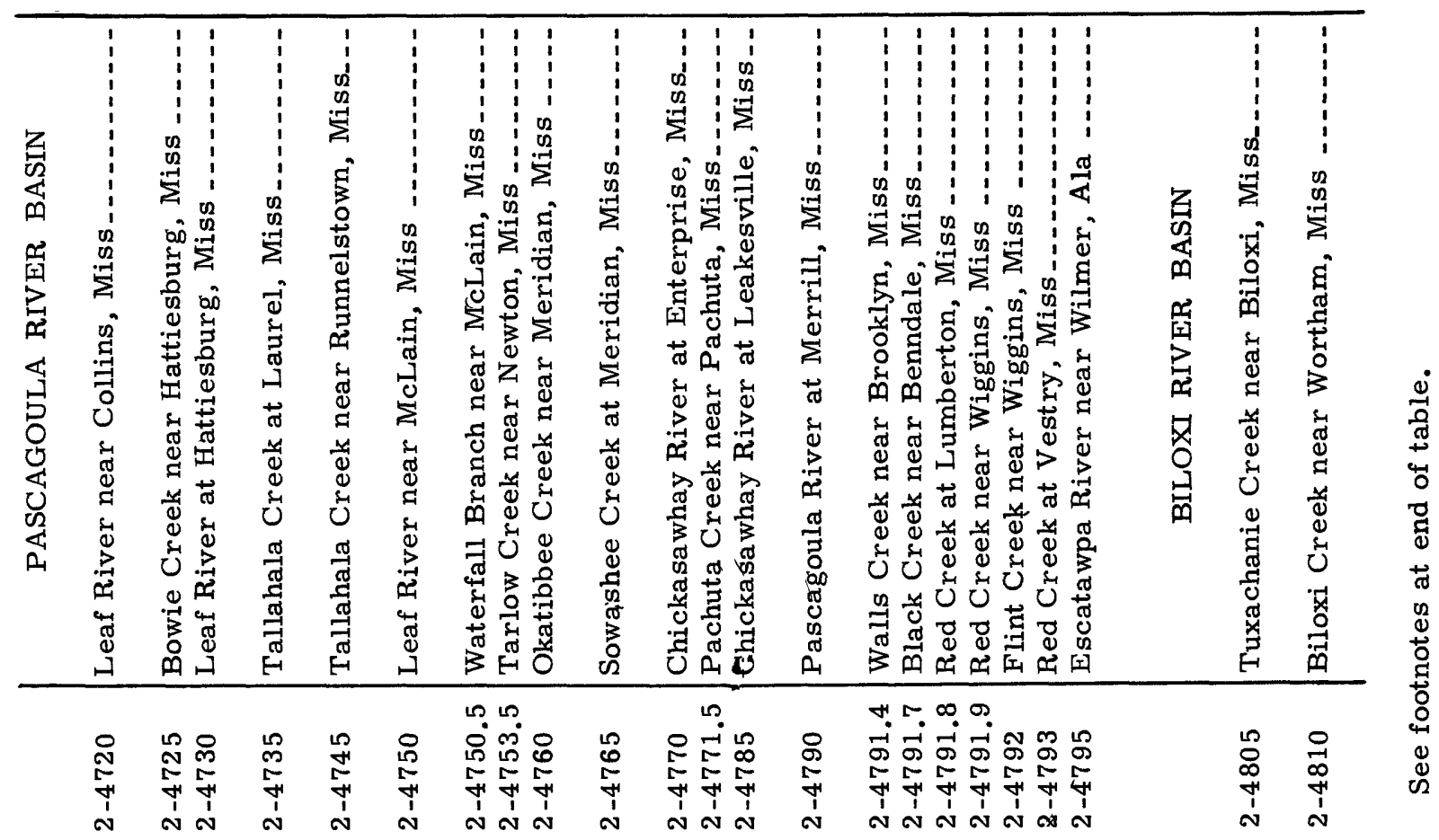




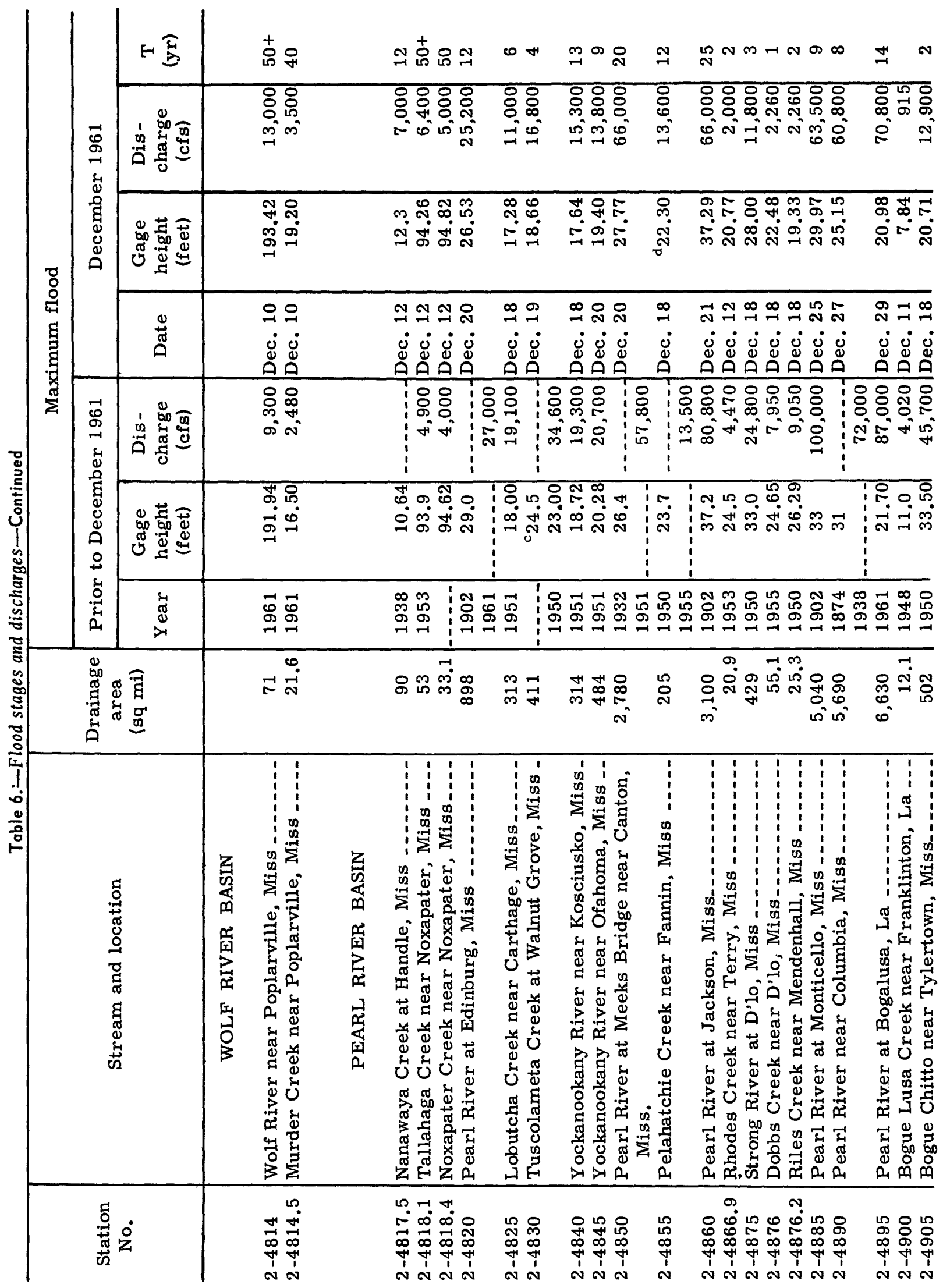




\begin{tabular}{|c|c|c|c|}
\hline مـ & $N M \rightarrow N N N \rightarrow N N H N$ & 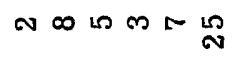 & H m \\
\hline ס & 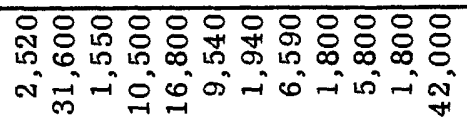 & 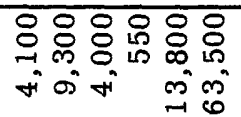 & 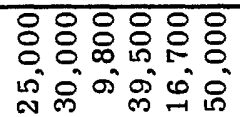 \\
\hline
\end{tabular}

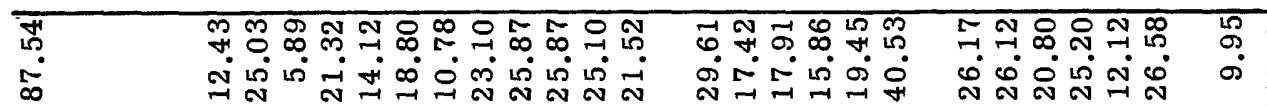

\begin{tabular}{|c|c|c|c|}
\hline 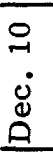 & 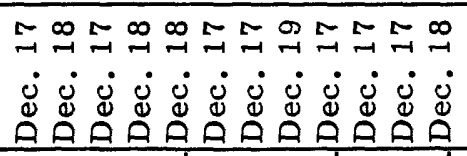 & 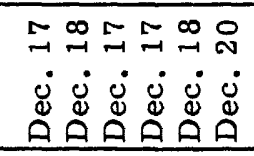 & 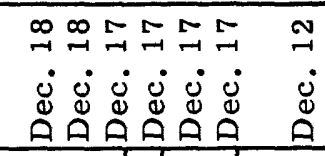 \\
\hline $\begin{array}{l}\text { O } \\
\text { D } \\
0\end{array}$ & 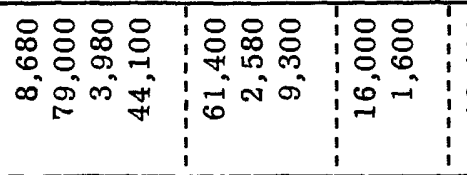 & 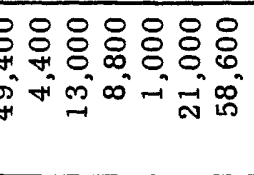 & 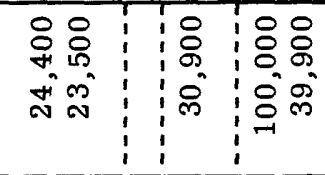 \\
\hline $\begin{array}{l}\infty \\
\stackrel{\infty}{\infty} \\
\infty\end{array}$ & 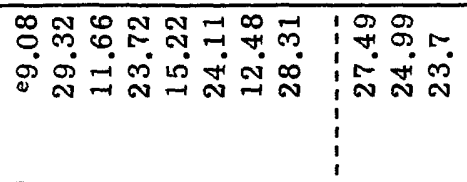 & 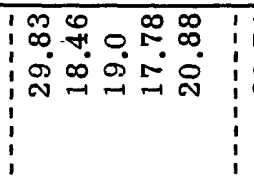 & 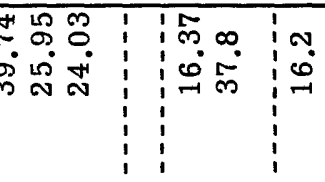 \\
\hline $\begin{array}{c}\infty \\
\substack{\mathscr{2} \\
\rightarrow-1}\end{array}$ & 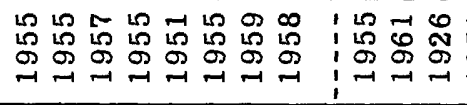 & مึ 대 & 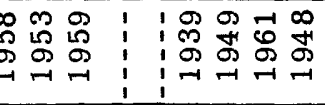 \\
\hline 오 & ণ̃ & 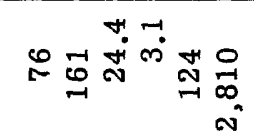 & 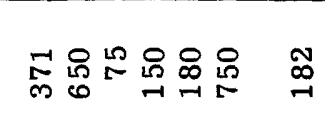 \\
\hline
\end{tabular}

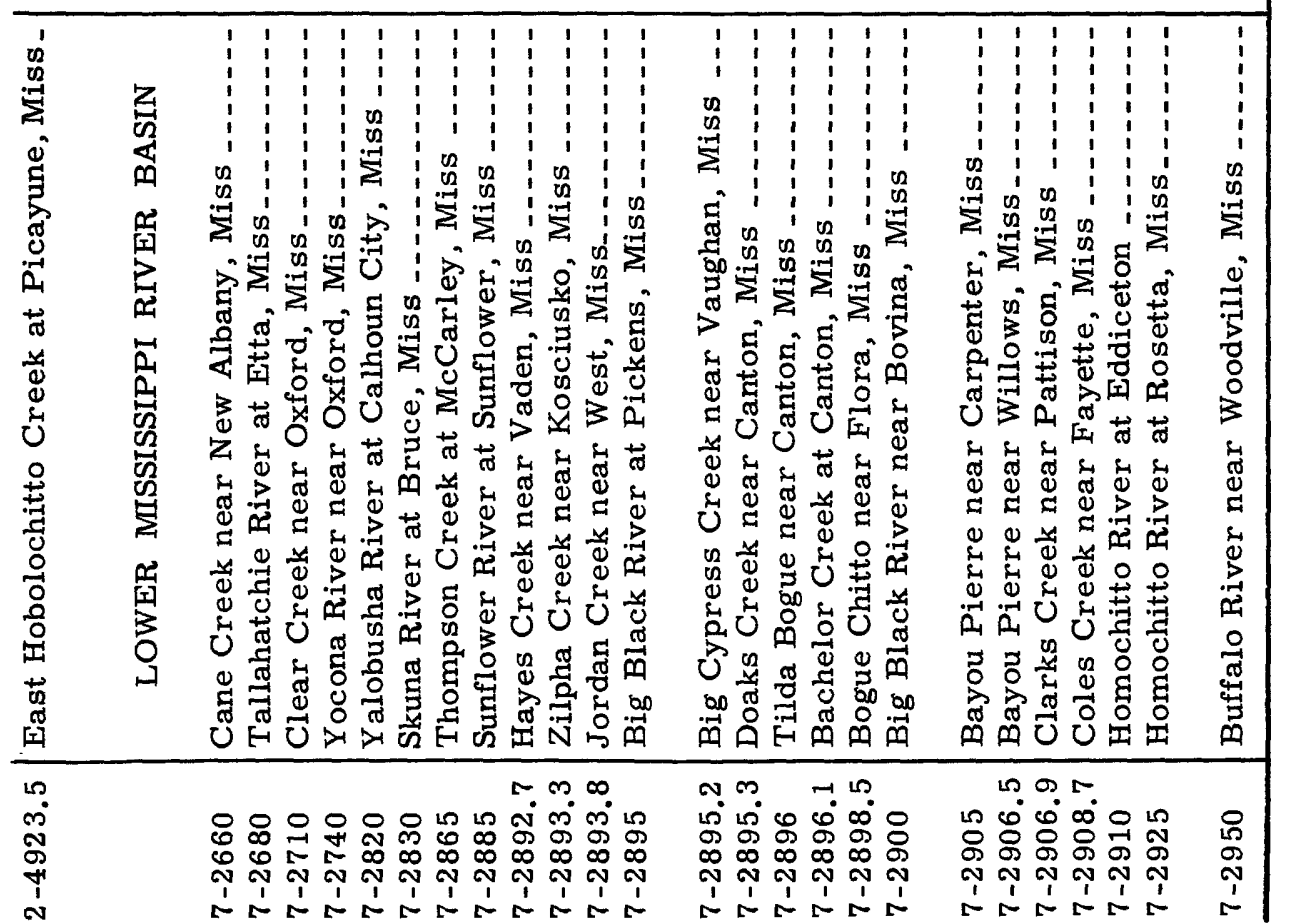

